\title{
BALTIC CONTEXT OF SOME ESTONIAN PERIPHRASTIC CAUSATIVE CONSTRUCTIONS
}

\author{
Jurgis Pakerys \\ Vilnius University
}

\begin{abstract}
I discuss 4 Estonian periphrastic causative constructions based on laskma, andma, panema, and sundima with respect to semantic shift from non-causative to causative use. These constructions have parallels in Baltic, and I suggest that laskma belongs to the largest area of development, 'release' > 'let', attested in many FinnoUgric and Indo-European languages, notably, in Germanic, Baltic, and to some extent, Slavic. The verb andma, which evolved as 'give' > 'let' ( $>$ 'be possible'), belongs to a smaller area of similar changes that occurred in Finnic, Baltic, and Slavic, while panema as 'put' > 'make' belongs to the smallest area (some Finnic and some Baltic languages). The verb sundima, as a Slavic loan, has parallel borrowings in a number of Finnic and Baltic languages, but only in Estonian has the causative use of this predicate developed.
\end{abstract}

Keywords: periphrastic causative constructions, factitive causative constructions, permissive causative constructions, Finnic languages, Baltic languages, Circum-Baltic area

DOI: https://doi.org/10.12697/jeful.2017.8.1.10

\section{Introduction}

It is well known that Finnic and Baltic languages have a number of common linguistic features also shared by some neighboring Germanic and Slavic languages; for an overview, see Koptjevskaja-Tamm, Wälchli (2001). In this article, I would like to discuss four Estonian predicates used in periphrastic causative constructions (hereafter, PCCs) within the context of the Baltic languages. I will focus on the semantic shift from non-causative to causative use paralleled by similar developments in the Baltic context and, when possible, I will also briefly mention the Finnic, Germanic, and Slavic context of corresponding PCCs.

The PCCs in this paper are understood as constructions with free verbal forms dedicated to the expression of causation, which can be either factitive, if the event is actively caused (cf. English make), or permissive, when the event is caused passively, that is, permitted, not blocked (cf. English let). The PCCs can be further subdivided into 
monoclausal, if the causative verb functions as an auxiliary and forms a cohesive unit with the lexical verb (cf. English make and let), and biclausal, if the clause with the causative verb can be shown to be separate from the one which marks the caused event (cf. English cause to). In this article, only the distinction between factitive and permissive subtypes will be made, and the issue of mono-/bi-clausality will be left out of the discussion. For further discussion of factitive, permissive, and mono-/bi-clausal types of PCCs, see Nedjalkov and Sil'nickij (1973), Dixon (2000), Kulikov (2001).

I have chosen four Estonian PCCs for the discussion for the following reasons (the numbers in parentheses indicate the sections of this article): (2) laskma 'let' is paralleled by Latvian laut, laist and Lithuanian leisti 'let' (< 'release'); (3) andma 'be possible' (< 'let') is to be compared with Latvian dot, Lithuanian duoti, Old Prussian dāt 'let' (< 'give'); (4) panema 'put; make' corresponds to Latvian likt 'put; make' and Latgalian stateit 'place; make'; (5) sundima 'make', a loanword from East Slavic, is paralleled by corresponding borrowings in all Baltic languages, where the causative use of these predicates has not developed. Estonian also has a number of other PCCs based on ajama 'make', lubama 'allow' and others, but the Baltic context of the constructions mentioned above are most relevant here. Further studies of Baltic and Finnic PCCs should reveal more possible parallels and important details of their development.

\section{2. laskma}

laskma exemplifies the rise of the permissive function 'let, allow' from 'release, let go', and both meanings coexist in modern Estonian: see the examples in (1a-b) as non-permissive vs. (1c) as permissive:

(1) Estonian ${ }^{1}$
a. kraani-st
vett
lask-ma
tap-ELA.SG water:PRT.SG pour-(m)INF
'to pour water from tap'
b. vangi-d las-ti vaba-ks
prisoner-NOM.PL release-PST.PASS free-TRA.SG
'prisoners were released'

1 All examples in (1) are from EE-RU, laskma. 


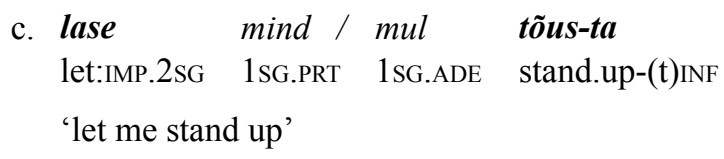

The development from 'release, let go' to 'let, allow' is also attested in Lithuanian, where both meanings co-exist synchronically, but the permissive function is clearly dominant and accounts for more than $70 \%$ of the use of this verb (Pakerys 2016: 439), cf. non-permissive (2a-b) vs. permissive (2c):

(2) Lithuanian (constructed; own knowledge)

a. leis-ti is čiaup-o vanden- $i$

pour-INF from tap-GEN.SG water-ACC.SG

'to pour water from tap'

b. kalini-ai buv-o pa-leis-t-i

prisoner-NOM.PL be-PST.3 PRF-release-PST.PASS.PTCP-NOM.PL.M

'prisoners were released'

c. leis-k man atsisto-ti

let-IMP.2SG 1sG.DAT stand.up-INF

'let me stand up'

Latvian has laist, which shares its root with Lithuanian leisti, but features a different apophonic grade (/ai/vs. /ei/). Permissive use of laist is marginal compared to that of laut (discussed below) and is attested in less than $12 \%$ of the tokens (Pakerys 2016: 453); see examples (3a-b) as non-permissive vs. (3c) as permissive:

(3) Latvian

a. lais-t ūden-i no krān-a

pour-INF water-ACC.SG from tap-GEN.SG

'to pour water from tap' (EE-LV, laskma)

b. Lais-t slimniek-u ārā no slimnīc-as

release-INF patient-ACC.SG outside from hospital-GEN.SG

'to release patient from hospital' (MLLV, laist) 
c. Lais-t bērn-iem izskrie-ties

let-INF child-DAT.PL have.a.good.run-INF.RFL

'to let the children have a good run (get tired with running about)' (LLVV, laist)

It is worth noting that the Latvian permissive laut only allows dative coding of the causee ('permittee'), while laist allows accusative and dative, the first case being more frequent (see Pakerys 2016: 453). I have no data on the frequency of use of adessive and partitive in Estonian laskma-construcions (cf. these cases in (1c), mind/mul), but it seems that adessive is the default option, while partitive is less common $^{2}$. As Klaas (1996: 56) notes, the use of adessive in this and some other constructions characterizes Estonian as being closer to the Indo-European pattern rather than the Finnic one. The gradual shift from non-dative marking of the causee to dative (= adessive in Estonian) may be related to the development of the manipulative meaning of the predicates discussed above and is in line with Givon's suggestion (2001: 66-68) that dative in some languages correlates with attempted manipulation (in our case, the manipulation is permissive).

Estonian laskma has given rise to the modal particle las $<$ imperative lase (Metslang 2000: 59) and it is worth noting that identical developments have also occurred in Baltic. Despite the rarity of the use of permissive laist in modern Latvian, the imperative form of this verb developed into a modal particle lai < laid (Endzelin 1922: 690) and this demonstrates that the permissive semantics of laist may have been more prominent in earlier stages (that is, frequent enough to give rise to lai). Some Lithuanian dialects have also developed the particle lai (Fraenkel 1962: 329), which also points to an earlier use of the verb *laisti (with /ai/ grade of the root) in Lithuanian. Old Prussian has a modal (conditional) suffix -lai, which, it has been suggested, may be related to the Lithuanian and Latvian particles discussed above, but this comparison is uncertain, see Stang (1966: 443), and no corresponding verb with the root *laid-/leid-is attested in Old Prussian. For more examples of the development of modal particles from permissive verbs in CircumBaltic and other languages, see Endzelin (1922: 690), Metslang (2000: 59-60); for a discussion and comparison of relevant constructions

2 Cf., for example, BED (http://www.eki.ee/dict/psv/index.cgi?Q=laskma\&F=M). See an overview and a more detailed discussion of marking of the causee and the caused event in laskma-constructions in (Tamm 2012). 
in Estonian, Livonian, Latvian, and Lithuanian, see Klaas-Lang and Norvik (2014: 599-600).

Latvian laut 'allow, let', currently the most commonly used permissive PCC, has no other synchronic uses, other than the idiomatic phrase ļaut valu + dative 'give way (for)'. Historically, Latvian ļaut also developed from 'release, let go' (Karulis 1992: 5523) and has correspondences in Lithuanian and Old Prussian, where it has not acquired a permissive function and means 'cease, stop' (Lithuanian reflexive liauti-s) or 'die' (Old Prussian prefixed au-lāut). It should also be noted that Estonian laskma differs from the Baltic counterparts in its ability to express factitive causation ('make; have smth. done') and verbal manipulation ('ask, order'); see Kasik (2001: 105-113), Tamm (2012).

The path of development from 'release, let go, leave' to 'let' is widely attested in Finno-Ugric ${ }^{4}$ and many Indo-European languages; of special interest from the areal perspective is the common Germanic development of *lète/a-, cf. Gothic letan, Old Norse láta, Old High German lâzan, among others (see EWahd 5 1073-1074). The Slavic languages also have some examples of this development, cf. Bulgarian puskam $+d a$-clause, Slovenian puščati + Inf-clause (Levshina 2015), Polish do-puścić + by-clause, Russian do-pustit'+ čtoby-clause, among others. More data are needed, but it seems that in the Slavic languages, the development 'release' > 'let' may have occurred later in comparison with other Circum-Baltic languages (for example, in many cases presented above, only finite subordinate clauses are available and infinitive clauses are not yet allowed). In this respect, (East) Baltic languages seem to be closer to Finnic and Germanic languages, with a fully developed shift from 'release, let go' to 'let' allowing infinitival complements.

3 The Indo-European base of this verb is either *leh $I^{-}$'nachlassen, (zu)lassen' (see LIV2 399 with the Baltic data), or *leu H- 'abschneiden, lösen' (see Smoczyński 2007: 349); on this root, see LIV2 (417), where the Baltic data are not included; see also ALEW (1576).

4 See UED (http://www.uralonet.nytud.hu/eintrag.cgi?id_eintrag=450) and EED (laskma). I have not checked the data of individual languages and have assumed the possibility of the permissive function based on the translations of meanings by German lassen. However, given the polysemy of lassen, not all Finno-Ugric verbs translated this way would necessarily be used in PCCs proper. 


\section{3. andma}

andma belongs to the chain of development from 'give' to 'let', and judging from the information given in bilingual dictionaries, it is typically used in impersonal constructions marking possibility. For example, EE-LV and EE-RU translate this use of andma as 'be possible' (būt iespējamam in Latvian and byt' vozmožnym in Russian), cf. (4a-b) as impersonal vs. (4c) where the use of andma is personal ('allow'). The shift from 'allow' to 'be possible' is reminiscent of the development of passive modal constructions from permissive reflexive 'give' -constructions in Polish and Czech, see (von Waldenfels 2012: 153-185, 222-231).

(4) Estonian

$\begin{array}{lll}\text { a. tema-ga } & \text { anna-b } & \text { rääki-da } \\ \text { 3SG-COM } & \text { be.possible-PRS.3SG } & \text { talk-(t)INF }\end{array}$

'It is possible to talk with him' (EE-LV, andma)

b. teg-i-me kõik, mis teha and-is do-PST-1PL everything what do:(t)INF be.possible-PST.3SG

'We did everything possible' (EE-LV, andma)

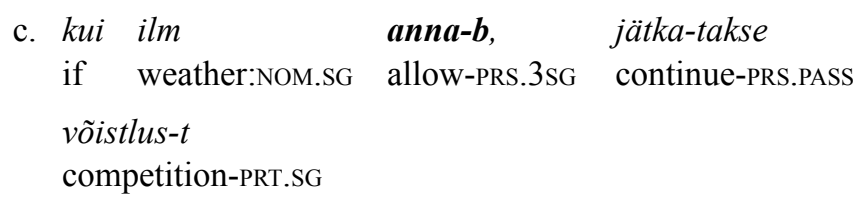

'Weather permitting, the competition will be continued' (EE-RU, andma)

Give-based PCCs are attested in all Baltic languages, but their use in modern Lithuanian and Latvian is marginal. Before turning to these East Baltic languages, let us briefly review the data of Old Prussian. The corpus of this extinct West Baltic language is limited, but luckily enough, the use of PCCs with $d \bar{a} t$ ' give' is attested. Due to the influence of German lassen-constructions, dāt can refer not only to permissive, but also to factitive situations (similarly to the Estonian laskmaconstruction discussed above $)^{5}$, cf. (5a) as permissive vs. (5b) as facti-

5 Due to limited data, we do not know if the factitive use of $d \bar{a} t$ was widespread, or if we are dealing with just an occasional translation of the German lassen-construction. 
tive (before the English translations, the original German sentences which were translated into Old Prussian are given):

(5) Old Prussian

a. Däiti ftans malnijkik-ans prē[ ]mien perēi-t let:IMP.2PL DEM:ACC.PL.M child-ACC.PL to 1sG.ACC come-INF 'Last die Kindlein zu Mir komen' (Ench 113, 2-3; 112, 2) = 'Let the children come to me' (ESVB, Mark 10:14)

b. Stwi dai Deiw-s ain-an gill-in

Here let:PST.3 god-NOM.SG one-ACC.SG.F deep-ACC.SG.F

\begin{tabular}{|c|c|c|c|}
\hline $\begin{array}{l}\text { maigg-un } \\
\text { sleep-ACC.SG }\end{array}$ & $\begin{array}{l}\boldsymbol{k} r \bar{u}-\boldsymbol{t} \\
\text { fall-INF }\end{array}$ & $\begin{array}{l}\text { no[ ] } \tan \\
\text { on DEM:ACC.SG.M }\end{array}$ & $\begin{array}{l}\text { fmunentin-an } \\
\text { man-ACC.SG }\end{array}$ \\
\hline
\end{tabular}

'Da ließ Gott der HERR einen tieffen Schlaff fallen / auff den Menschen' (Ench 101, 12; 100, 10-11) = 'So the LORD God caused a deep sleep fall upon the man' (ESVB, Genesis 2:21)

In Lithuanian and Latvian, give-based PCCs are used marginally, alongside the main PCCs with leisti in Lithuanian and laut in Latvian (Pakerys 2016: 443-445, 454), cf. (6a) and (6b):

(6) a. Lithuanian

$\begin{array}{lllll}\text { [Jis] dažnai } & \text { duod-a } & \text { vairuo-ti } & \text { automobil- } i \\ \text { 3SG.NOM often } & \text { allow-PRS.3 } & \text { drive-INF } & \text { car-ACC.SG } \\ \text { kit-iems } & \text { asmen-ims } & & \\ \text { other-DAT.PL.M } & \text { person-DAT.PL }\end{array}$

'[He] frequently allows other persons to drive his car' 6

b. Latvian

$\begin{aligned} & \text { Bērn-iem tagad dod vadī-t autobus-u? } \\ & \text { child-DAT.PL now allow:PRS.3 drive-INF bus-ACC.SG }\end{aligned}$
'Do they now allow children to drive buses?'

Restricted use of permissive give-based PCCs is most probably due to the expansion of leisti in Lithuanian and laut in Latvian. The Old

6 http://eteismai.lt/byla/179371597263552/II-78-718, 2016-04-15.

7 http://www.tvnet.lv/auto/satiksme/357628_pie_lido_no_kupenas_izvelk_autobusu_ kura_brauca_berni/comments, 2010-12-12. 
Prussian data show that the shift 'give' > 'let' could be either a common Baltic innovation, or an independent (parallel) development shared by a number of neighboring Slavic ${ }^{8}$ and Finnic languages. In Finnic, 'give' $>$ 'let' is attested in Livonian, Votic, Finnish, Ingrian, Livvi-Karelian, and Veps'. Again, this may be either an archaic (common-Finnic?) development, or a later parallel shift, but in both cases, the Finnic languages belong to a larger area of Baltic and Slavic languages characterized by the development 'give' $>$ 'let'.

Compared to the shift 'release' > 'let', the development 'give' > 'let' has a different distribution in Europe with respect to Germanic and Slavic languages. As noted earlier, 'release' > 'let' is widely attested in Germanic, while 'give' > 'let' seems to be less common ${ }^{10}$. Slavic languages, on the other hand, share an early development 'give' $>$ 'let' (the change 'release' > 'let' is also attested, but it may be less archaic, cf. above). In this context, Baltic and Finnic languages seem to form a transitional zone. On the one hand, Finnic features the 'release' $>$ 'let' shift shared by many Finno-Ugric languages, while the development 'give' > 'let' is shared by Finnic languages only. The Baltic languages (Latvian and Lithuanian) are characterized by the 'release' > 'let' shift, which also occurred in Germanic languages (the roots of corresponding verbs are slightly different, but could ultimately go back to the same source $^{11}$ ), and at the same time, the Baltic languages also feature a 'give' > 'let' development shared with Slavic languages (the verb is etymologically the same).

\section{4. panema}

In the case of panema, the meaning 'put, place' synchronically coexists with 'make', and the causative use is noted as the most frequent of all grammatical functions of this verb (Tomson 2016: 70-71), cf. (7):

8 In light of the possibility of a shift from 'give' > 'let' in Proto-Slavic, one could also even imagine a common Balto-Slavic development, but this change could have occurred independently, reflecting areal trends. See von Waldenfels $(2012: 2,247)$ on 'give' > 'let' as a Proto-Slavic change.

9 I have counted the languages for which the meaning 'lubada' (= 'let, allow') was indicated in EED (http://www.eki.ee/dict/ety/index.cgi? $\mathrm{Q}=$ andma\&F=M).

10 See Newman (1996: 189-190) on English give as 'enable, permit' (19th c. examples) and on German and English constructions belonging to the "give someone to think" type (Newman 1996: 186-187).

11 See (Fraenkel 1962: 352, ALEW 1 567). 
(7) Estonian

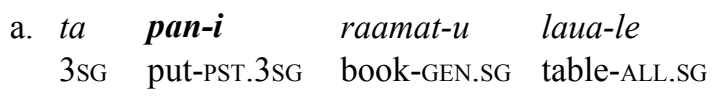

'He put the book on the table' (EE-LV, panema)

b. probleemi-d pan-i-d meid mõtle-ma

problem-NOM.PL make-PST-3PL 1PL:PRT think-(m)INF

'The problems made us think' (EE-LV, panema)

Neighboring Latvian exhibits the same polysemy with likt, which means 'make' alongside 'put' (it should be noted that dictionaries tend to present this as a case of homonymy), cf. (8):

(8) Latvian

a. Es konspekt-us un grāmat-as lik-u zem spilven-a

$1 \mathrm{SG}$ notes-ACC.PL and book-ACC.PL put-PST.3 under pillow-GEN.SG

'I put [lecture] notes and books under the pillow'12

b. veselīb-as problēm-as lik-a aizdomā-ties

health-GEN.SG problem-NOM.PL make-PST.3 think-INF.RFL

$\begin{array}{lll}\text { par } & \text { garīg-ām } & \text { liet-ām } \\ \text { about } & \text { spiritual-DAT.PL.F } & \text { thing-DAT.PL }\end{array}$

'Health problems made [me] think about spiritual things $[\ldots]]^{13}$

Despite synchronic similarity, the development of these meanings in Estonian and Latvian seems to be different. In the case of Estonian, 'put' probably gave rise to 'make' directly, whereas Latvian likt 'make' could have developed from 'leave' (cf. prefixed pa-likt 'leave') via the intermediate stage of 'let'; the same meaning ('leave') also gave rise to 'put' in Latvian (see ME II 469, cf. also Karulis 1992: 536). The change from 'leave' to 'let' is well attested ${ }^{14}$, and the development 'let' > 'make' is also quite frequent (e.g. German lassen). This last change led to the synchronic coexistence of 'put' and 'make' in Latvian, paralleled in Estonian and some other Finnic languages (e.g. Finnish panna, Livonian $p \bar{a} n d a$, etc.). From the areal point of view, Finnic interference in

12 http://cosmo.lv/forums/topic/141615-pirmseksamena-manticibas/, June 6, 2013.

$13 \mathrm{http}: / / \mathrm{www}$.marcisjencitis.lv/zinas/draudzes-zinas/pecaizlugsanaskluvatikvieglikaaizmirsuparslimibu, August 16, 2016.

14 See Soares da Silva (2007: 185-192); for a list of languages with the development 'leave' > 'let', see p. 189. 
the formation of this combination of meanings in Latvian seems likely, but further research is needed to establish the details of the development of causative use of Latvian likt and also of corresponding lexemes in the neighboring Finnic languages. An alternative scenario would be to assume direct change from 'put' to 'make' in Latvian following the Finnic pattern, but I currently lack evidence for this shift.

A direct change from 'put, place' to 'make' is attested in Latgalian and perhaps in dialectal Lithuanian, where etymologically identical verbs, Latgalian stateit, Lithuanian statyti 'put, place' $(<$ 'put into vertical position'), acquired (or may acquire) this function. First, let us consider the Latgalian verb in (9a) as 'place' and (9b) as 'make':

(9) Latgalian

a. statej-a butel-i iz gold- $a$

put-PST.3 bottle-ACC.SG on table-GEN.SG

'[someone] placed a bottle on the table' (Reksēna 1998: 437)

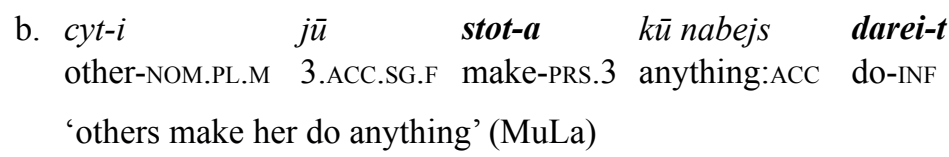

The factitive meaning of stateit ('make') is listed by a number of Latgalian dictionaries, and a preliminary search in the corpus of modern Latgalian (MuLa) confirms the current use of it, but it should be noted that stateit is used alongside the much more frequent likt (= Latvian likt). In the case of dialectal Lithuanian, data on the factitive use of statyti are very limited, and available examples seem to be still ambiguous, as one may interpret them as 'putting, placing' someone in a certain place of work, activity, as in (10):

(10) (dialectal) Lithuanian

$\begin{array}{lllll}\text { Pri-stat- } \dot{\boldsymbol{e}} & \text { riešut- } \boldsymbol{u} & \text { mal-t }- & \text { ne-pamali-au, } \\ \text { PRF-put-PST.3 } & \text { nut-GEN.PL } & \text { grind-INF } & \text { NEG-be.able.to.grind-PST.1SG } \\ \text { stat- } \dot{\boldsymbol{e}} & \check{z} \text { virzd- } \underline{u} & \text { grūs- } t i & \text { ne-pagrūd-au } \\ \text { put-PST.3 } & \text { gravel-GEN.PL } & \text { pound-INF } & \text { NEG-be.able.to.pound-PST.1SG }\end{array}$

'They made/put me (to) grind nuts and I could not grind them, they made/ put me to pound gravel and I could not pound it' (LKŽe, statyti)

Among Slavic languages, one could note Russian za-stavit' 'make' alongside stavit' 'put into vertical position; place'. However, judging 
from the data presented in the historical dictionary of Russian (SRJA 27: 177-180), the non-prefixed staviti never had a causative meaning ('make'), and probably only prefixed za-staviti acquired this function, which developed from 'block' (by putting, placing something as an obstacle) or similar meaning. More data are needed, but if that were the case, then the development 'put, place' > 'make' in Latgalian ${ }^{15}$ and (dialectal) Lithuanian seems to be independent from East Slavic and not borrowed from it. However, it is also clear that Latgalian and Lithuanian, when in contact with East Slavic (Russian or Belarussian), show interference at the level of perfectivizing prefixation: Latgalian aiz-stateit 'make' (perfective) and Lithuanian (dialectal) už-statyti 'make' (perfective) directly correspond to East Slavic za-stavit' (alongside other prefixed perfective formations: Latgalian da-stateit, Lithuanian pri-statyti).

To conclude, the history of the development and coexistence of the meanings 'put, place' and 'make' in the area under discussion is more complicated than the cases of 'release' $>$ 'let' and 'give' $>$ let' described earlier. It is clear that we are dealing with a rather small area of development for 'put, place' > 'make' (or simply the coexistence of these meanings), compared to a large-scale area of development 'release' > 'let' (Finno-Ugric, Germanic, Baltic, etc.) and a middle-scale area for 'give' $>$ 'let' (Finnic, Baltic, Slavic). The area of 'put, place' > 'make' includes some Finnic languages and some Baltic data (Latgalian, rarely, dialectal Lithuanian; in Latvian, 'make' does not seem to be directly derivable from 'put'). The development of za-stavit' in East Slavic belongs to a different type ('block' > 'make'), unless the rise of the zastavit'construction can be explained otherwise (i.e. stavit' 'place' > 'make', with a subsequent perfectivization by $z a$-). Of the other languages outside the Circum-Baltic area with a 'put' > 'make' shift, one might mention, for example, Romanian (a pune $+s \check{a}+\mathrm{V}$ in subjunctive), see Levshina (2015).

15 Latgalian is considered to be one of the macrolanguages of Latvia, together with Latvian. 


\section{5. sundima}

sundima 'make' is interesting in that it is a borrowing from East Slavic (< sqditi/suditi 'judge'); see EED (sundima) and Blokland (2005: $377)^{16}$. This verb was also borrowed into other Finnic languages (Livonian sund, Votic süntiä, Finnish suntia, see EED (sundima)), but none of these seems to have developed causative use. Blokland (2005: 377) notes that the meaning of the corresponding noun sundija (borrowed from Old Russian sudbja 'judge' or, less probably, derived from the borrowed verb sundima) acquired the meaning glossed in German as 'Triber' ( $<$ 'Richter') after the second half of the 17th c., which means that sundima may have also developed the sense 'make, force, etc.' around that time. The Baltic languages also copied the same Slavic verb: the East Baltic languages transferred it from East Slavic when the nasal vowels were already lost there (Latvian sodìt 'punish', Latgalian sūdeit 'punish', (dialectal and earlier written) Lithuanian südyti 'judge'; cf. reborrowing in (dialectal) Estonian, see fn. 16), while West Baltic (Old Prussian) borrowed Polish sadzić > *sündītvei $>$ *sūndintvei 'strafen = punish' (incorrectly printed as sñndintwti in Ench 39,1), Mažiulis 2013: 870). Contrary to Estonian and similarly to some Finnic languages mentioned above, the Baltic languages did not develop the meaning 'make, force' from this loanword. In this case, the shift from 'judge' to 'force, make' occupies the smallest area compared to other cases of semantic changes discussed in preceding sections.

\section{Conclusions}

1. Estonian laskma represents a shift from 'release' to 'let', widely attested in many Finno-Ugric and Indo-European languages, notably in neighboring Germanic and Baltic (Lithuanian leisti, Latvian ļaut, laist). More data are needed, but it may be the case that similar developments occurred comparatively later in Slavic languages. The imperative form of Estonian laskma gave rise to the modal particle las, and this development is paralleled in Baltic (Lithuanian lai, Latvian lai), as well as in neighboring Germanic and Slavic languages.

16 It was later reborrowed once again as (dialectal) Estonian sudi(ta)ma 'to force, etc.' < Russian sudi-t'/-ti (Blokland 2005: 377, fn. 260 with further reference). 
2. Estonian andma belongs to the development from 'give' to 'let' (and further to 'be possible'). The shift 'give' > 'let' is also attested in other Finnic, Slavic and all Baltic languages, but the use of give-based PCCs in modern Latvian and Lithuanian is limited. With respect to Slavic and Germanic, Baltic and Finnic languages seem to form a transitional zone, where both developments ('give' > 'let' and 'release' > 'let') are well-attested.

3. Possible comparanda for Estonian panema ('put, place' > 'make') are Latvian likt 'put; make' and Latgalian stateit 'put, place; make'; the data of dialectal Lithuanian are scarce. However, it should be noted that Latvian 'make' may have evolved from 'let' (< 'leave'), which is a different path from that of Estonian and other Finnic languages, if we assume a direct shift from 'put' to 'make' there. Finnic influence on the formation of this set of meanings for Latvian likt is possible, but further research is needed to determine the details.

4. Slavic verbs meaning 'judge' were borrowed into a number of Finnic and Baltic languages, but only in Estonian has this loan acquired a causative function.

5. According to the size of the area in which a particular semantic shift (or coexistence of certain meanings) is attested, the Estonian predicates discussed in this article can be arranged in the following order: laskma ('release' > 'let') > andma ('give' > 'let') > panema ('put' > 'make', 'put' and 'make') > sundima ('judge'> 'make').

\title{
Acknowledgments
}

I would like to sincerely thank the anonymous reviewer and Miina Norvik for their comments, suggestions, and explanations, which helped me improve this text. I am also very grateful to Virve Vihman for careful editing of my article. Needless to say, all possible misinterpretations and errors are mine.

\author{
Address: \\ Jurgis Pakerys \\ Vilnius University \\ Faculty of Philology, Department of Baltic Studies \\ Universiteto 5 \\ 01513 Vilnius, Lithuania \\ E-mail: jurgis.pakerys@flf.vu.lt
}




\begin{abstract}
Abbreviations
1 - 1st person, 2 - 2nd person, 3 - 3rd person, ACC - accusative, ADE - adessive, ALL - allative, COM - comitative, CONNEG - connegative, DAT - dative, DEM - demonstrative, ELA - elative, F - feminine, GEN - genitive, IMP - imperative, INF - infinitive $((\mathrm{m})$ INF or $(\mathrm{t})$ INF in Estonian), M - masculine, NEG - negation, NOM - nominative, PASS passive, PL - plural, PRF - prefix, PRS - present, PRT - partitive, PST past, PTCP - participle, $\mathrm{RFL}-$ reflexive, $\mathrm{SG}-$ singular, TRA - translative
\end{abstract}

\title{
References
}

Blokland, Rogier Philip Charles Eduard (2005) The Russian loanwords in literary Estonian. PhD thesis. University of Groningen. Available online at $<\mathrm{http}$ ://www.rug.nl/ research/portal/publications/the-russian-loanwords-in-literary-estonian(8264c9a97a21-4ce2-a526-d0c03bef17da)/export.html). Accessed on November-December, 2016.

Dixon, Robert M. W. (2000) "A typology of causatives: form, syntax and meaning”. In Robert M. W. Dixon and Aleksandra Yu. Aikhenvald, eds. Changing valency. Case studies in transitivity, 30-83. Cambridge: Cambridge University Press.

DOI: $10.1017 /$ CBO9780511627750.003.

Endzelin, Jan (1922) Lettische Grammatik. Heidelberg: Winter.

Fraenkel, Ernst (1962) Litauisches etymologisches Wörterbuch 1. Heidelberg: Carl Winter.

Givón, Talmy (2001) Syntax: An introduction 2. Amsterdam, Philadelphia: John Benjamins.

Karulis, Konstantīns (1992) Latviešu etimologijas vārdnīca 1. Rīga: Avots.

Kasik, Reet (2001) “Analytic causatives in Estonian". In Mati Erelt, ed. Estonian: Typological Studies V, 77-122. (Tartu Ülikooli eesti keele õppetooli toimetised 18.) Tartu.

Klaas-Lang, Birute and Miina Norvik (2014) "Balti areaali tüpoloogilisi sarnasusi morfosüntaksi valdkonnas." Keel ja Kirjandus 8-9, 590-608.

Klaas, Birute (1996) "Similarities in case marking of syntactic relations in Estonian and Lithuanian." In Mati Erelt, ed. Estonian: Typological Studies 1, 37-67. (Tartu Ülikooli eesti keele õppetooli toimetised 4.) Tartu.

Koptjevskaja-Tamm, Maria and Bernhard Wälchli (2001) “The Circum-Baltic languages: An areal-typological approach”. In Östen Dahl, Maria Koptjevskaja-Tamm, eds. Circum-Baltic languages 2: Grammar and typology, 615-750. Amsterdam, Philadelphia: John Benjamins.

Kulikov, Leonid (2001) “Causatives”. In Martin Haspelmath, Ekkehard König, Wulf Oesterreicher, and Wolfgang Raible, eds. Language typology and language universals. An international handbook 2, 886-898. Berlin, New York: Walter de Gruyter. 
Levshina, Natalia (2015) "European analytic causatives as a comparative concept. Evidence from a parallel corpus of film subtitles". Folia Linguistica 49(2), 487-520.

Mažiulis, Vytautas (2013) Prūsu kalbos etimologijos žodynas. Vilnius: Mokslo ir enciklopedijų leidybos centras. Available online at $<$ http://www.prusistika.flf.vu.lt/ zodynas/paieska $>$. Accessed on December, 2016.

Metslang, Helle (2000) "Reflections on development of a particle in Estonian". In Mati Erelt, ed. Estonian: Typological Studies IV, 59-86. (Tartu Ülikooli eesti keele õppetooli toimetised 14.) Tartu.

Nedjalkov, Vladimir P. and Georgij G. Sil'nickij (1973) "The typology of morphological and lexical causatives". In Ferenc Kiefer, ed. Trends in Soviet theoretical linguistics, 1-32. Dordrecht etc.: Reidel.

Newman, John (1996) Give: A cognitive linguistic study. Berlin: Mouton de Gruyter.

Orel, Vladimir (2003) A handbook of Germanic etymology. Leiden: Brill.

Pakerys, Jurgis (2016) "On periphrastic causative constructions in Lithuanian and Latvian”. In Axel Holvoet and Nicole Nau, eds. Argument realization in Baltic, 427-458. Amsterdam, Philadelphia: John Benjamins.

Reķēna, Antoņina (1998) Kalupes izloksnes vārdnīca 2: N-Ž [Kalupe subdialect dictionary]. Rīga: Latviešu valodas institūts.

Smoczyński, Wojciech (2007) Słownik etymologiczny języka litewskiego. Vilnius: Vilniaus universiteto leidykla.

Soares da Silva, Augusto (2007) "Verbs of letting: Some cognitive and historical aspects". In Nicole Delbecque and Bert Cornillie, eds. On interpreting construction schemas. From action and motion to transitivity and causality, 171-200. Berlin: Mouton de Gruyter.

Stang, Christian S. (1966) Vergleichende Grammatik der baltischen Sprachen. Oslo, Bergen, Tromsö: Universitetsforlaget.

Tamm, Anne (2012) "Let me introduce the Estonian analytical causatives: the permissive and factitive laskma 'let, make, have, allow, permit"'. In Jaakko Leino, Ruprecht von Waldenfelds, eds. Analytical causatives: from 'give' and 'come' to 'let' and 'make', 247-289. München: Lincom Europa.

Tomson, Kairit (2016) Panema-verbi polüseemia ja kasutus grammatilistes konstruktsioonides. MA thesis. University of Tartu. Available online at $<$ http://dspace.ut.ee/ bitstream/handle/10062/51758/Tomson._MAG.pdf>. Accessed on 09.02.2017.

von Waldenfels, Ruprecht (2012) The grammaticalization of 'give' + infinitive: a comparative study of Russian, Polish, and Czech. Berlin, Boston: De Gruyter Mouton.

\section{Sources}

ALEW 1 = Wolfgang Hock, ed. Altlitauisches etymologisches Wörterbuch 1. Hamburg: Baar, 2015.

BED = Basic Estonian dictionary. Eesti Keele Instituut, 2014. Available online at $<$ http://www.eki.ee/dict/psv/>. Accessed on November-December, 2016. 
EE-LV = Eesti-läti sõnaraamat, Eesti Keele Instituut, 2015. Available online at $<$ http://www.eki.ee/dict/et-lv/>. Accessed on November-December, 2016.

EE-RU = Eesti-vene sõnaraamat . Eesti Keele Instituut, 1997-2009. Available online at $<$ http://portaal.eki.ee/dict/evs/>. Accessed on November-December, 2016.

$\mathrm{EED}=$ Etymological dictionary of Estonian. Eesti Keele Instituut, 2012. Available online at $<\mathrm{http} / / / \mathrm{www}$.eki.ee/dict/ety/>. Accessed on November-December, 2016.

Ench = Der Kleine Catechifmus Doctor Martin Luthers Deutfch vnd Preuffifch [...]. Königsberg: Johann Daubmann, 1561. Available online at $<$ http://www.prusistika. flf.vu.lt/tekstai/paieska/?saltinis=III\&puslapis=17>. Accessed on December, 2016.

$\mathrm{ESVB}=$ English standard version Bible. Available online at $<$ http://www.esvbible.org $>$. Accessed on December, 2016.

EWahd 5 = Rosemarie Lühr, ed. Etymologisches Wörterbuch des Althochdeutschen 5 (iba-luzzilo). Göttingen: Vandenhoeck \& Ruprecht, 2014.

LIV $^{2}=$ Helmut Rix, ed. Lexikon der indogermanischen Verben. Wiesbaden: Reichert, 2001.

LKŽe = Lietuviu kalbos žodynas 1-20 [Dictionary of the Lithuanian Language], electronic edition, ed. by Gertrūda Naktinienè (editor in chief), Jonas Paulauskas, Ritutė Petrokienė, Vytautas Vitkauskas, Jolanta Zabarskaitè. Vilnius: Lietuvių kalbos institutas, 2005-2008. Available online at: $<\mathrm{http}: / /$ www.lkz.lt $>$. Accessed on November-December, 2016.

LLVV = Latviešu literārās valodas vārdnīca. Apgāds "Zinātne", LU Matemātikas un informātikas institūts, LU Latviešu valodas institūts, 1972-2010. Available online at $<$ http://tezaurs.lv/llvv/>. Accessed on November-December, 2016.

$\mathrm{ME}=K$. Mühlenbachs lettisch-deutsches Wörterbuch. Redigiert, ergänzt und fortgesetzt von Jan Endzelin. Riga: Lettisches Bildungsministerium, 1923-1932. Available online at $<\mathrm{http} / /$ tezaurs.lv/mev/>. Accessed on December, 2016.

MLLV = Mūsdienu latviešu valodas vārdnīca, ed. by Ieva Zuicena, LU Latviešu valodas institūts, 2003-2013. Available online at $<\mathrm{http} / /$ tezaurs.lv/mlvv/>. Accessed on November-December, 2016.

MuLa = Mūsdienu latgaliešu tekstu korpuss, 1987-2012 [Corpus of modern Latgalian, 1987-2012]. Available online at < http://hipilatlit.ru.lv/bonito/run.cgi/first_form>. Accessed on November-December, 2016.

SRJA 27 = Slovar' russkogo jazyka XI-XVII vv. 27. Moskva: Nauka, 2006.

$\mathrm{UED}=$ Uralic Etymological Database. Available online at

$<$ http://www.uralonet.nytud.hu>. Accessed on November-December, 2016.

Kokkuvõte. Jurgis Pakerys: Mõnede eesti keele perifrastiliste kausatiivkonstruktsioonide balti kontekst. Artiklis võetakse verbide laskma, andma, panema ja sundima näitel vaatluse alla eesti keele perifrastiline kausatiivkonstruktsioon. Autor keskendub verbide tähendusnihetele mittekausatiivsest kasutusest kausatiivse suunas. Konstruktsioonidel on vasted balti keeltes. Autori hinnangul kuulub verb laskma ('lahti laskma' > 'laskma') suurimasse muutusalasse, s.t seda leidub paljudes soome-ugri ja indoeuroopa keeltes, sh 
germaani, balti, mingil määral ka slaavi keeltes. Verb andma, mis on läbi teinud arengu 'andma' > 'laskma'(>'võimalik olema'), kuulub väiksemasse läänemeresoome, balti ja slaavi keeltes toimunud sarnaste muutuste areaali. Verb panema ('panema' > 'sundima') kuulub kõige väiksemasse muutusalasse, esinedes vaid mõnes läänemeresoome ja balti keeles. Verbil sundima on slaavi laenuna vasteid mitmes läänemeresoome ja balti keeles, kuid kausatiivne kasutus on sel predikaadil välja kujunenud vaid eesti keeles.

Märksõnad: perifrastilised kausatiivkonstruktsioonid, faktitiivsed kausatiivkonstruktsioonid, permissiivsed kausatiivkonstruktsioonid, läänemeresoome keeled, balti keeled, Balti areaal 